\title{
Characteristics and Formation Mechanism of Inclusions in 304L Stainless Steel during the VOD Refining Process
}

\author{
Xingrun Chen ${ }^{1,2, *}$, Guoguang Cheng ${ }^{1, *}$, Jingyu $\mathrm{Li}^{1}$, Yuyang Hou ${ }^{1}$, Jixiang Pan ${ }^{2}$ \\ and Qiang Ruan ${ }^{2}$ \\ 1 State Key Laboratory of Advanced Metallurgy, University of Science and Technology Beijing, \\ Beijing 100083, China; b20160493@xs.ustb.edu.cn (J.L.); hyyustb@gmail.com (Y.H.) \\ 2 Hongxing Iron \& Steel Co. Ltd., Jiuquan Iron and Steel Group Corporation, Jiayuguan 735100, China; \\ panjixiang@jiugang.com (J.P.); ruanqiang@jiugang.com (Q.R.) \\ * Correspondence: chenxingrun@jiugang.com (X.C.); chengguoguang@metall.ustb.edu.cn (G.C.); \\ Tel.: +86-106-233-4664 (X.C. \& G.C.)
}

Received: 27 October 2018; Accepted: 29 November 2018; Published: 5 December 2018

\begin{abstract}
The formation and characteristics of non-metallic inclusions in 304L stainless steel during the vacuum oxygen decarburization (VOD) refining process were investigated using industrial experiments and thermodynamic calculations. The compositional characteristics indicated that two types of inclusions with different sizes (from $1 \mu \mathrm{m}$ to $30 \mu \mathrm{m}$ ) existed in 304L stainless steel during the VOD refining process, i.e., $\mathrm{CaO}-\mathrm{SiO}_{2}-\mathrm{Al}_{2} \mathrm{O}_{3}-\mathrm{MgO}$ external inclusions, and $\mathrm{CaO}-\mathrm{SiO}_{2}-\mathrm{Al}_{2} \mathrm{O}_{3}-\mathrm{MgO}-$ $\mathrm{MnO}$ endogenous inclusions. The calculation results obtained using the FactSage 7.1 software confirmed that the inclusions that were larger than $5 \mu \mathrm{m}$ were mostly $\mathrm{CaO}-\mathrm{SiO}_{2}-\mathrm{Al}_{2} \mathrm{O}_{3}-\mathrm{MgO}$; the similarity in composition to the slag indicated that these inclusions originated from the slag entrapment. The $\mathrm{CaO}-\mathrm{SiO}_{2}-\mathrm{Al}_{2} \mathrm{O}_{3}-\mathrm{MgO}-\mathrm{MnO}$ inclusions that were smaller than $5 \mu \mathrm{m}$ originated mainly from the oxidation reaction with $\mathrm{Ca}, \mathrm{Al}, \mathrm{Mg}, \mathrm{Si}$, and $\mathrm{Mn}$. The changes in the inclusion composition resulting from changes in the $\mathrm{Ca}, \mathrm{Al}$, and $\mathrm{O}$ contents, and the temperature during the VOD refining process was larger for the smaller inclusions. Generating mechanisms for the $\mathrm{CaO}-\mathrm{SiO}_{2}-\mathrm{Al}_{2} \mathrm{O}_{3}-\mathrm{MgO}-\mathrm{MnO}$ inclusions in the $304 \mathrm{~L}$ stainless steel were proposed.
\end{abstract}

Keywords: 304L stainless steel; non-metallic inclusions; formation mechanism; VOD refining

\section{Introduction}

In recent years, 304L stainless steel has been rapidly developed, and it is widely used in shipbuilding, offshore drilling platform construction, metal structures for construction of buildings and bridges, containers and cisterns, flux-cored wire, and in industrial transport machinery engineering, petrochemical engineering, nuclear power engineering, etc. [1-4]. Because of its harsh application environment, the requirements for $\mathrm{C}, \mathrm{N}, \mathrm{P}, \mathrm{S}$, and $\mathrm{O}$ elements are stringent, the production is difficult, and the added value of the products is high. In addition to the control of the metal elements, the control of inclusions is also the key to improving the quality of $304 \mathrm{~L}$ stainless steel.

The control of the composition, quantity, and size of the inclusions at the beginning of their formation is likely to become a new and effective method to reduce the harmful influence of the inclusions. Therefore, it is very important to investigate the source and formation mechanism of the inclusions [5-18]. The formation of non-metallic inclusions of Si-killed stainless steel during the GOR (gas oxygen refining) process has been reported by Li et al. [7]. The authors found that the inclusions that were larger than $5 \mu \mathrm{m}$ and contained more than $30 \% \mathrm{CaO}$ were attributed to the modification of slag droplets through the oxidation of $\mathrm{Si}$ and $\mathrm{Al}$ and the collision with deoxidation-type 
inclusions; in addition, the degree of change was larger for the smaller inclusions. A tracer was used by Kim et al. [8] to determine the source of the large inclusions (larger than $20 \mu \mathrm{m}$ ) in 304 stainless steel, and it was found that these inclusions originated from the slag entrapment. This result was confirmed by the study of Ehara et al. [9], who also pointed out that the oxidation of $\mathrm{Si}$ and $\mathrm{Al}$ on the surface of slag inclusions can lead to the increase in the $\mathrm{SiO}_{2}$ and $\mathrm{Al}_{2} \mathrm{O}_{3}$ contents. Yin et al. [10] reported that after de-oxidation with $\mathrm{Si} / \mathrm{Mn}$ additions, spherical complex inclusions mainly consisting of calcium silicates were observed. The contents of $\mathrm{MgO}$ and $\mathrm{Al}_{2} \mathrm{O}_{3}$ in these inclusions continuously increased as the steel moved from the argon-oxygen decarburization (AOD) through ladle processing to the tundish. Park et al. [11] reported that the inclusions mainly consisted of $\mathrm{Al}_{2} \mathrm{O}_{3}$ when the $\mathrm{Al}$ content was higher than $0.05 \%$. Ren et al. [12] pointed out that a high-basicity slag improved the cleanness of stainless steel, whereas a low basicity slag lowered the $\mathrm{Al}_{2} \mathrm{O}_{3}$ content in the inclusions, thereby lowering the melting temperature of the inclusions and improving the deformability of the inclusions. This result was confirmed by the studies of Yan et al. [13,14] and Sakata [15].

However, in previous studies on the formation of inclusions, only a single factor was considered, namely external inclusions or endogenous inclusions. The formation mechanism of both types of inclusions has not been clarified to date. In the present study, the $304 \mathrm{~L}$ stainless steel was produced by the process route of basic oxygen furnace (BOF)-AOD-vacuum oxygen decarburization (VOD)-ladle furnace (LF)-continuous casting (CC). The characteristics and generating mechanism of the inclusions during the VOD refining process were investigated using industrial experiments and thermodynamic calculations with FactSage 7.1 software; in addition, a formation mechanism for non-metallic inclusions occurring in the VOD refining process was proposed.

\section{Experiments}

\subsection{Experimental Procedure and Sampling}

The smelting process route of 304L stainless steel consisted of BOF-AOD-VOD-LF-CC. The molten iron from the blast furnace was used as the raw material, and it was directly poured into the AOD furnace for decarburization and denitrification treatments after the dephosphorization pre-treatment; the target values of the carbon and nitrogen content were $0.30-0.50 \%$ and less than $0.08 \%$, respectively and ferrosilicon was used for the $\mathrm{Cr}$ reduction in the AOD process. The slag was tapped after the AOD process, and then the ladle (the refractory material was magnesia-calcium) was hung to the VOD for deep decarburization and denitrification; ferrosilicon was used for $\mathrm{Cr}$ reduction in the VOD process, and subsequently, the liquid steel was poured into the LF furnace. When the temperature and composition of the liquid steel met the requirements, it was transported to the platform for CC.

The VOD consists of three stages: (i) oxygen blowing: oxygen was blown onto the melt at $1000-1500 \mathrm{~m}^{3} / \mathrm{h}$ for $40-60 \mathrm{~min}$. Argon was injected at 200-600 L/min through two porous bricks at the bottom of the ladle. Lime was charged to form a basic slag. The total pressure was maintained at between 2.6 and $16 \mathrm{kPa}$; (ii) vacuum carbon deoxidation (VCD): the total pressure was reduced to between 26.6 and $66.5 \mathrm{~Pa}$ for 10-15 min without any additions of oxygen, fluxes, or ferroalloys. The bottom stirring argon flow rate was increased to $800-1000 \mathrm{~L} / \mathrm{min}$ because at this stage of very low carbon contents, the decarburization is controlled by the rate of mass transfer of carbon and oxygen in the bath. The oxygen content was $0.015 \%$ after the VCD stage; (iii) reduction: ferrosilicon was added as a reducing agent for the chromium oxide in the slag. The aluminum content of the ferrosilicon was $1.3 \%$. The final steel temperature was $1600{ }^{\circ} \mathrm{C}$.

In order to elucidate the formation of the nonmetallic inclusions in the 304L stainless steel, a steel sample was taken at the end of the VOD and was immediately quenched in water. A slag sample was taken after the VOD treatment. 


\subsection{Composition Analysis and Inclusion Characterization}

The chemical composition of the steel samples were determined by a direct reading of the spectrum (ARL4460, Thermo Fisher Scientific, Waltham, MA, USA). The contents of C and S were analyzed by a C/S analyzer (CS-800, ELTRA, Haan, Germany). Cylinders ( $\Phi 5 \mathrm{~mm} \times 5 \mathrm{~mm})$ were machined for the measurement of the total oxygen contents, which were analyzed using the inert gas fusion-infrared absorptiometry method. The acid-soluble Al and Ca contents in the steel were determined using the inductively coupled plasma optical emission spectroscopy method (ICP-OES). The composition of the slags was analyzed by an X-ray fluo-rescence spectrometer (ARL PERFORM'X, Thermo Fisher Scientific, Waltham, MA, USA).

The morphologies of the inclusions in the specimens were observed using scanning electron microscopy (Merlin Compact, Zeiss, Gottingen, Germany) (SEM). The $15 \mathrm{~mm} \times 15 \mathrm{~mm} \times 10 \mathrm{~mm}$ samples for the SEM analysis were made by cutting, grinding, and polishing. The chemical compositions of the inclusions were analyzed with an energy dispersive spectrometer (X-Max 80, Oxford Instruments, High Wycombe, UK) (EDS) to determine the inclusion type. A quantitative analysis of the inclusions was performed using the INCA software (Inca Energy 250, Oxford Instruments, High Wycombe, UK) of the scanning electron microscope. To ensure good accuracy for the automated EDS analysis of the inclusions, the size of the inclusions was larger than $1 \mu \mathrm{m}$ because the interaction volume may spread into the steel and excite electrons from the environment surrounding the inclusions if the diameters are smaller than $1 \mu \mathrm{m}$.

\section{Results}

\subsection{Composition of the Molten Steel and Slag}

The averages of the chemical compositions of the molten steel and slag after the VOD stage are listed in Tables 1 and 2, respectively. It can be seen that after the VOD treatment, the contents of C and $\mathrm{N}$ in steel were $0.008 \%$ and $0.015 \%$ respectively. The oxygen content and sulfur content were higher because of deep degassing. The $S$ content after VOD reached $30 \mathrm{ppm}$, indicating that the oxygen potential was higher in the molten steel, which was consistent with the conclusion drawn from the test results of the slag. Conversely, the slag and steel continuously reacted with each other during the VOD refining process, and the slag-steel balance was finally achieved. The contents of $\mathrm{Cr}_{2} \mathrm{O}_{3}$ and FeO in the slag were much higher after VOD refining, and were $0.43 \%$ and $0.15 \%$, respectively.

Table 1. Chemical composition of 304L after vacuum oxygen decarburization (VOD) treatment (wt \%).

\begin{tabular}{ccccccccccccc}
\hline Stage & $\mathbf{C}$ & $\mathbf{S i}$ & $\mathbf{M n}$ & $\mathbf{P}$ & $\mathbf{S}$ & $\mathbf{N i}$ & $\mathbf{C r}$ & $\mathbf{C a}$ & $\mathbf{A l}$ & $\mathbf{N}$ & $\mathbf{M g}$ & $\mathbf{O}$ \\
\hline VOD & 0.008 & 0.22 & 1.14 & 0.015 & 0.003 & 8.04 & 18.00 & 0.002 & 0.004 & 0.015 & 0.0005 & 0.007 \\
\hline
\end{tabular}

Table 2. Chemical composition of 304L slag after VOD treatment (wt \%).

\begin{tabular}{ccccccc}
\hline Stage & $\mathrm{CaO}$ & $\mathrm{SiO}_{2}$ & $\mathrm{MgO}$ & $\mathrm{Al}_{2} \mathbf{O}_{3}$ & $\mathrm{Cr}_{2} \mathrm{O}_{3}$ & $\mathrm{FeO}$ \\
\hline VOD & 59.16 & 29.12 & 5.97 & 1.87 & 0.43 & 0.15 \\
\hline
\end{tabular}

\subsection{Characterization of the Inclusions}

The morphology and the compositions of the inclusions in the molten steel after the VOD process are shown in Figure 1. It was observed that two types of inclusions existed in the 304L steel after the VOD process. The first type of inclusions were spherical $\mathrm{CaO}-\mathrm{SiO}_{2}-\mathrm{Al}_{2} \mathrm{O}_{3}-\mathrm{MgO}$ with sizes ranging from several to tens of microns at the end of the VOD smelting (Figure 1a). These inclusions contained a small amount of aluminum. The second type consisted of endogenous inclusions with a size smaller than $5 \mu \mathrm{m}$, and a different composition. The common types of inclusions were $\mathrm{CaO}-\mathrm{SiO}_{2}-\mathrm{Al}_{2} \mathrm{O}_{3}-\mathrm{MgO}-\mathrm{MnO}$, which represented the dominant type, as shown in Figure $1 b$. 


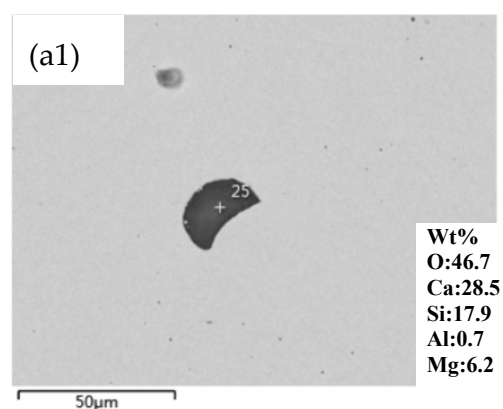

(b1)

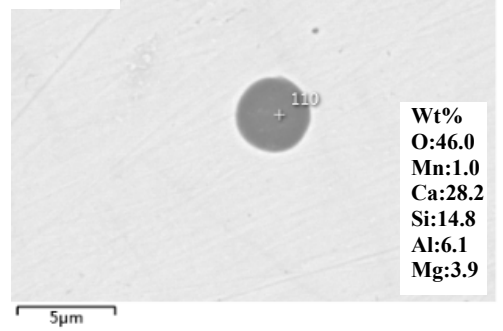

(a2)

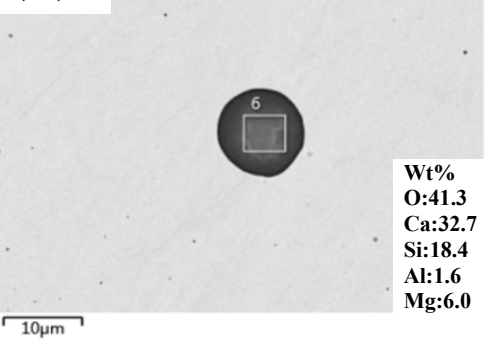

(b2)

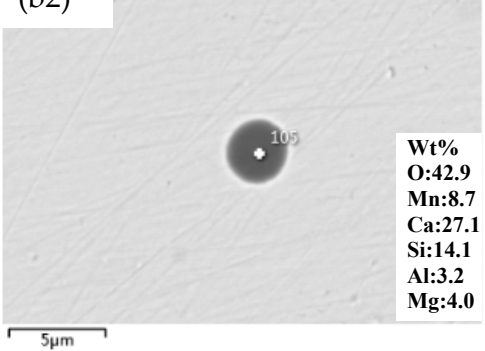

(a3)

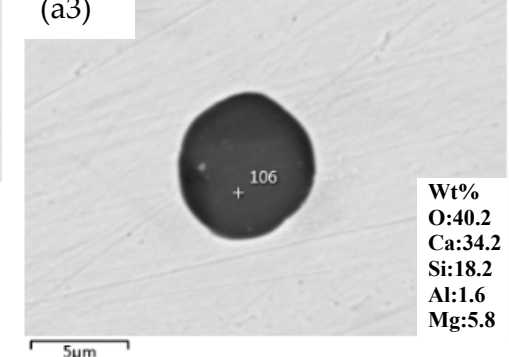

(b3)

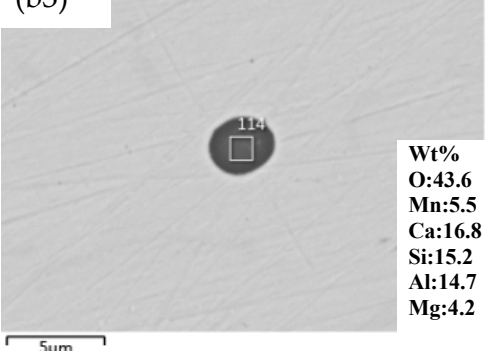

Figure 1. Morphology of typical inclusions encountered in the samples: (a) $\mathrm{CaO}-\mathrm{SiO}_{2}-\mathrm{MgO}-\mathrm{Al}_{2} \mathrm{O}_{3}$; (b) $\mathrm{CaO}-\mathrm{SiO}_{2}-\mathrm{Al}_{2} \mathrm{O}_{3}-\mathrm{MgO}-\mathrm{MnO}$.

\subsection{Corresponding Relation between the Size and Composition of the Inclusions}

The mass fractions of $\mathrm{CaO}, \mathrm{SiO}_{2}, \mathrm{Al}_{2} \mathrm{O}_{3}, \mathrm{MgO}$, and $\mathrm{MnO}$ of the inclusions of various sizes were calculated using the mass fraction derived from the EDS, as shown in Figure 2. It can be clearly seen that the inclusion composition exhibited changes with the increase in size from $1 \mu \mathrm{m}$ to $30 \mu \mathrm{m}$. Most inclusions were smaller than $5 \mu \mathrm{m}$. We created two categories based on the relationship between the size and mass percent of composition, i.e., larger than $5 \mu \mathrm{m}$ and smaller than $5 \mu \mathrm{m}$. The inclusions that were larger than $5 \mu \mathrm{m}$ had almost the same $\mathrm{CaO}, \mathrm{SiO}_{2}, \mathrm{MgO}$, and $\mathrm{Al}_{2} \mathrm{O}_{3}$ contents, but the $\mathrm{MnO}$ contents were very low. The composition differed for the inclusions that were smaller than $5 \mu \mathrm{m}$. The contents of $\mathrm{SiO}_{2}, \mathrm{CaO}$, and $\mathrm{Al}_{2} \mathrm{O}_{3}$ fluctuated in a wide range from 0 to more than $30 \%$. The $\mathrm{MnO}$ contents increased markedly from 0 to more than $10 \%$ as the size of the inclusions decreased. To correlate the compositions of inclusions (size smaller than $5 \mu \mathrm{m}$ ), the inclusions were plotted on the ternary system, as shown in Figure 3. It was shown that the inclusion quantity increased with the inclusion size decreasing. The contents of $\mathrm{SiO}_{2}, \mathrm{CaO}$, and $\mathrm{Al}_{2} \mathrm{O}_{3}$ fluctuated in a wide range, but the contents of $\mathrm{MgO}$ and $\mathrm{MnO}$ had smaller variation of range.
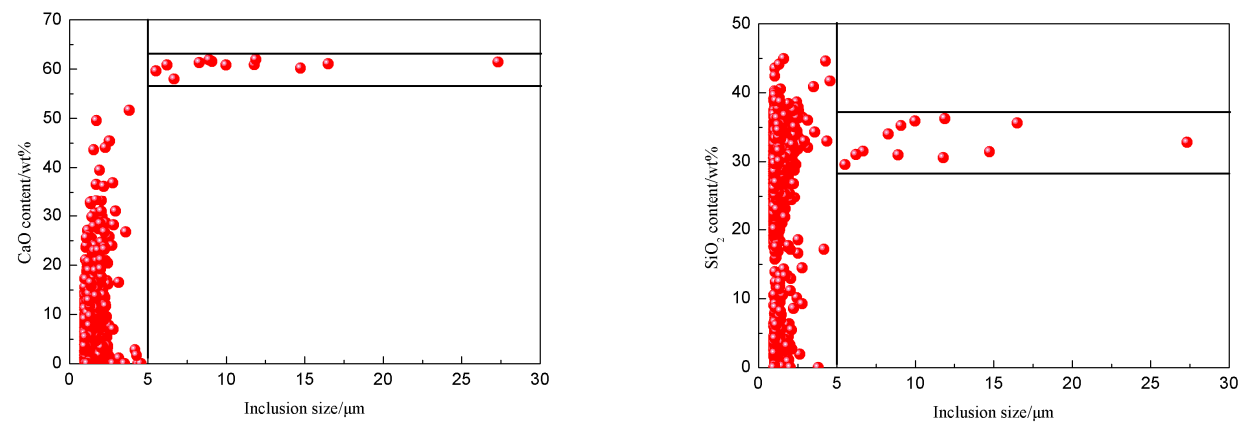

Figure 2. Cont. 

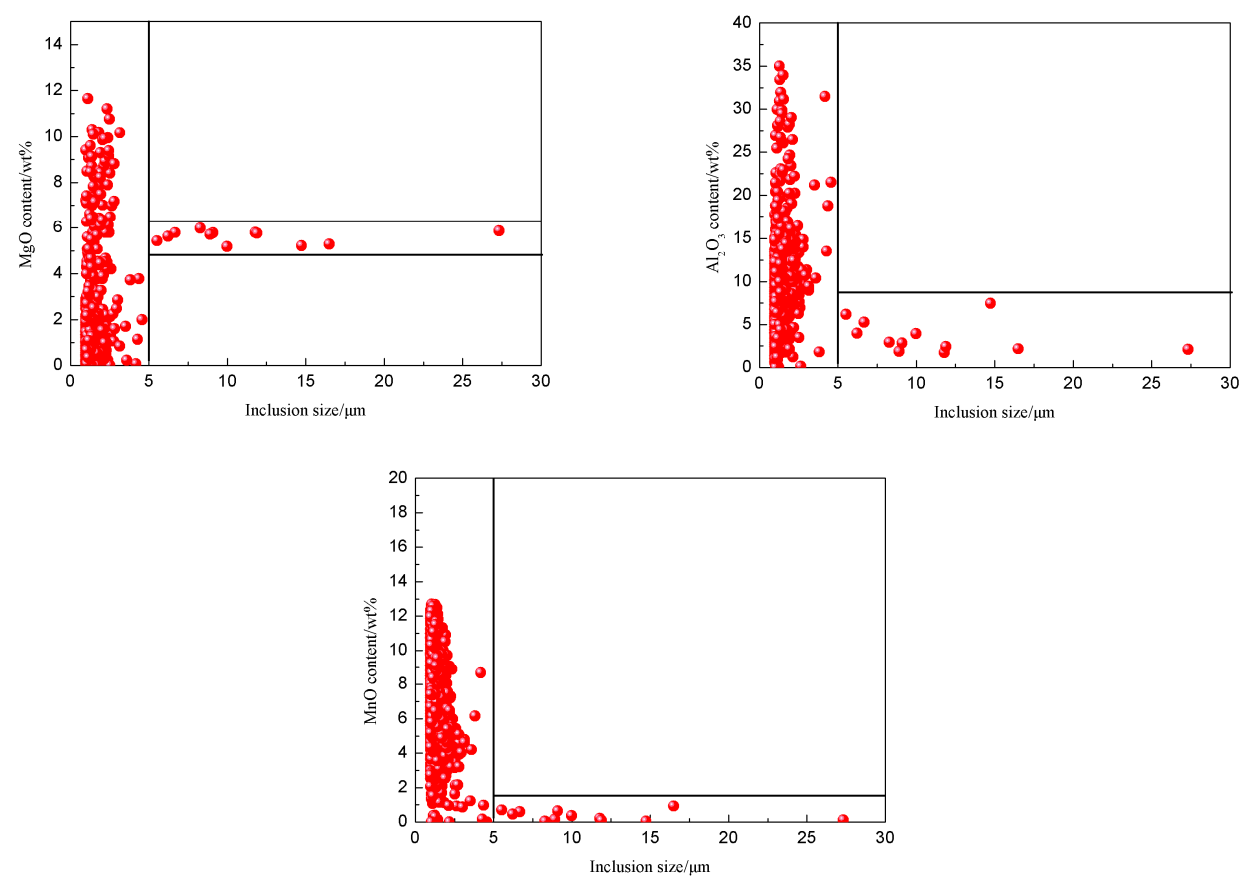

Figure 2. The relationship between inclusion size and inclusion content.
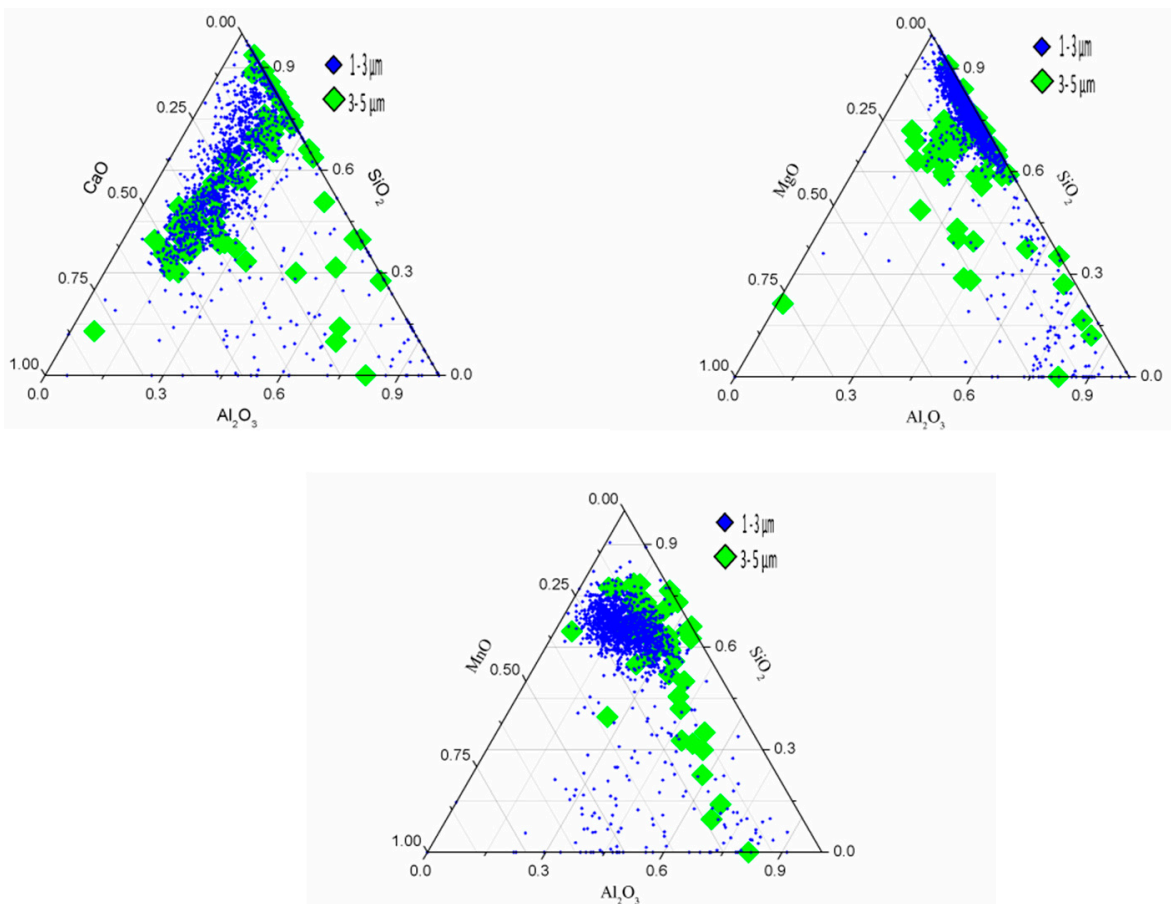

Figure 3. Composition distributions (mass fraction) of inclusions (size smaller than $5 \mu \mathrm{m}$ ).

\section{Discussion}

The compositional characteristics shown in Figures 2 and 3 indicate that two types of inclusions existed in the 304L stainless steel during the VOD refining process, i.e., the $\mathrm{CaO}-\mathrm{SiO}_{2}-\mathrm{Al}_{2} \mathrm{O}_{3}-\mathrm{MgO}$ external inclusions that were larger than $5 \mu \mathrm{m}$, and the $\mathrm{CaO}-\mathrm{SiO}_{2}-\mathrm{Al}_{2} \mathrm{O}_{3}-\mathrm{MgO}-\mathrm{MnO}$ endogenous inclusions that were smaller than $5 \mu \mathrm{m}$. The composition of the inclusions in the same sample showed a large difference. Therefore, the source and the formation process of the inclusions are likely different; this is discussed in detail in the following sections. 


\subsection{Generating the Mechanism of $\mathrm{CaO}-\mathrm{SiO}_{2}-\mathrm{MgO}-\mathrm{Al}_{2} \mathrm{O}_{3}$ Inclusions}

Figure 4 shows the $\mathrm{CaO}-\mathrm{SiO}_{2}-\mathrm{Al}_{2} \mathrm{O}_{3}$ phase diagram of the inclusions (larger than $5 \mu \mathrm{m}$ ) and their composition during the VOD process. The composition of the slag and the average composition of the inclusions are listed in the figure. It can be clearly seen that the compositions of the inclusions were in good agreement with slag composition. The inclusions consisted mostly of slag components, and they originated from slag entrapment. In addition, the $\mathrm{Al}_{2} \mathrm{O}_{3}$ contents in the inclusions were very low, and were very close to that of the slag. The $\mathrm{MgO}$ contents in the inclusions in the VOD process were also close to that of the slag. Therefore, it can be concluded that the inclusions that were larger than $5 \mu \mathrm{m}$ during the VOD process were mainly derived from the entrapment of the top slag. The strong argon stirring in the VOD smelting causes the inclusions to be directly or indirectly in equilibrium between the molten steel and slag. Thus, the control of the inclusions can be achieved by controlling the slag composition. The $\mathrm{CaO}$ and $\mathrm{SiO}_{2}$ contents were higher in some inclusions. The main reason was that some inclusions such as $\mathrm{CaSiO}_{3}$ contain a higher content of $\mathrm{SiO}_{2}$, and $\mathrm{Ca}_{2} \mathrm{SiO}_{4}$ contains a higher content of $\mathrm{CaO}$ precipitated in the cooling process. The oxidations of $\mathrm{Si}$ and $\mathrm{Al}$ on the surfaces of some inclusions led to increases in the $\mathrm{SiO}_{2}$ and $\mathrm{Al}_{2} \mathrm{O}_{3}$ contents.

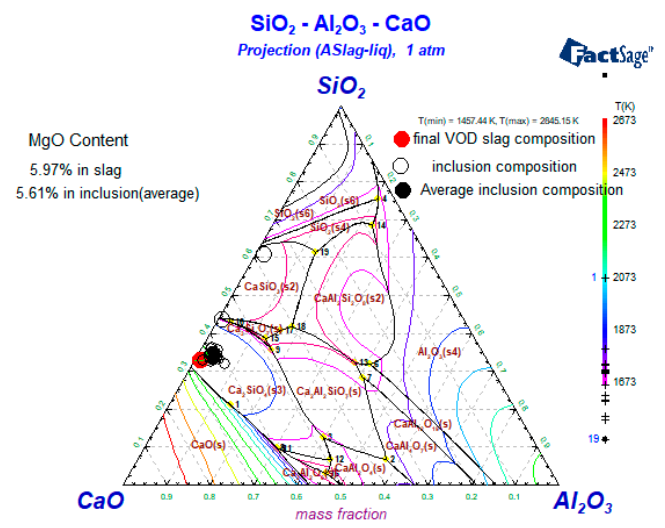

Figure 4. Chemical composition of the inclusions (larger than $5 \mu \mathrm{m}$ ) and the slag during the VOD process.

Qian [19] reported that the flow velocity at the critical interface between the steel and slag was $0.65 \mathrm{~m} / \mathrm{s}$. When the flow velocity at the interface was larger than the critical velocity, droplets formed and were entrapped into the molten steel; the average size of the slag droplets from the top slag gradually decreased with increasing velocity at the interface.

The stirring intensity of the argon blowing during the VOD reduction stage was $800-1000 \mathrm{~L} / \mathrm{min}$, which was far stronger than the argon blowing intensity of 200-400 L/min during the LF stage [20,21]; therefore, the velocity at the interface between the steel and slag was greater than $2 \mathrm{~m} / \mathrm{s}$. The reaction between the slag and steel was very intense during the VOD refining process and the droplets were strongly mixed and changed into very small particles; as a result, the minimum size of the droplets during VOD refining was $5 \mu \mathrm{m}$.

\subsection{Generating the Mechanism of $\mathrm{CaO}-\mathrm{SiO}_{2}-\mathrm{Al}_{2} \mathrm{O}_{3}-\mathrm{MgO}-\mathrm{MnO}$ Inclusions}

Factsage (Factsage ${ }^{\mathrm{TM}} 7.1$, Thermfact/CRCT \& GTT-Technologies, Aachen, Germany) was used for the thermodynamic calculations of the inclusions in the $304 \mathrm{~L}$ stainless steel during the VOD refining process; the databases FTmisc and FToxid were used, and the calculation module was Equilib with $100 \mathrm{~g}$ of molten steel. Due to the local non-uniformities of composition and temperature in molten steel during the VOD refining process, the elements with local fluctuations in concentrations in the molten steel had a wide range of concentrations and temperatures compared to the other components determined after the VOD. Figure 5 shows the inclusion composition as a function of the oxygen concentration when the $\mathrm{Al}$ content, Ca content, $\mathrm{Mg}$ content and the temperature is $0.004 \%, 0.002 \%$, 
$0.0005 \%$, and $1600{ }^{\circ} \mathrm{C}$ respectively. The $\mathrm{CaO}$ concentration exhibits a steady increasing trend with a decrease in the oxygen concentration, whereas the $\mathrm{MgO}$ and $\mathrm{SiO}_{2}$ concentrations exhibit a stable trend, and the $\mathrm{MnO}$ concentration decreases. However, the $\mathrm{Al}_{2} \mathrm{O}_{3}$ concentration remains steady at an oxygen concentration range from $0.015 \%$ to $0.011 \%$, and then gradually decreases with decreasing oxygen content at oxygen concentrations of less than $0.011 \%$. The oxygen concentration is at $150 \mathrm{ppm}$ after the VOD refining process, and at this stage, the elements compete with each other for oxidation as ferrosilicon is added for deoxidation. During the alloying deoxidation, strong oxidizing elements such as $\mathrm{Ca}$ and $\mathrm{Al}$ react with and consume some of the oxygen. However, since the concentration of $\mathrm{Si}$ in the molten steel is high, the deoxidation reaction of $\mathrm{Si}$ also takes precedence. The $\mathrm{Mg}$ concentration is at a low level, resulting in a low concentration of $\mathrm{MgO}$ in the inclusion. Moreover, the remaining oxygen reacts with weak oxidizing elements such as $\mathrm{Mn}$, leading to a small amount of $\mathrm{MnO}$ in the inclusions. With continuing deoxidation, the $\mathrm{Al}_{2} \mathrm{O}_{3}$ and $\mathrm{MnO}$ concentrations decrease, triggering an increase in the $\mathrm{CaO}$. During the VOD refining process, the oxygen content fluctuates with the deoxidation reaction, causing the fluctuations in each component of the endogenous inclusions that are smaller than $5 \mu \mathrm{m}$.

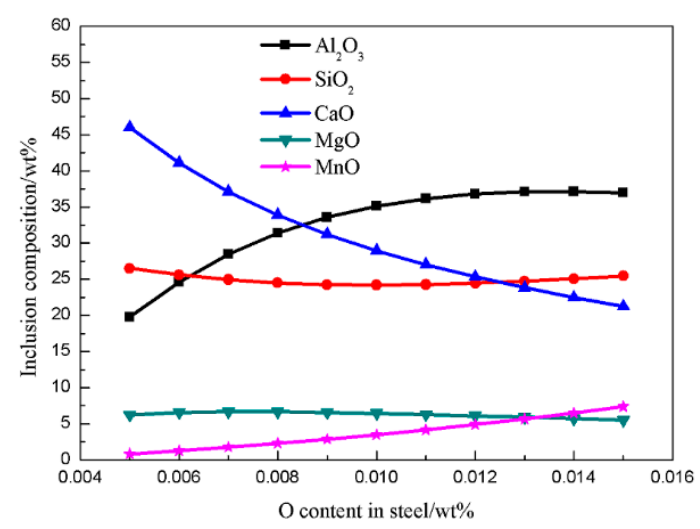

Figure 5. Inclusion composition as a function of the $\mathrm{O}$ content.

To determine the effect of $\mathrm{Ca}$ on the inclusions, the inclusion composition as a function of increasing Ca content was calculated using the FToxid and FTmisc databases of Factsage ${ }^{\mathrm{TM}} 7.1$ when the $\mathrm{O}$ content, $\mathrm{Al}$ content, $\mathrm{Mg}$ content, and the temperature is $0.007 \%, 0.004 \%, 0.0005 \%$, and $1600{ }^{\circ} \mathrm{C}$, respectively (Figure 6). It was observed that an increase in the Ca content results in an increase in the $\mathrm{CaO}$ and $\mathrm{SiO}_{2}$ contents, and a decrease in the $\mathrm{Al}_{2} \mathrm{O}_{3}$ content; however, the $\mathrm{MgO}$ and $\mathrm{MnO}$ contents did not change much. The Ca was mainly derived from the metal-slag reaction, the metal-refractory reaction, and the $\mathrm{Ca}$ from the FeSi alloy during the VOD refining process; this resulted in fluctuations in the Ca content. This is one reason for the fluctuations in the composition of the endogenous inclusions that are smaller than $5 \mu \mathrm{m}$.

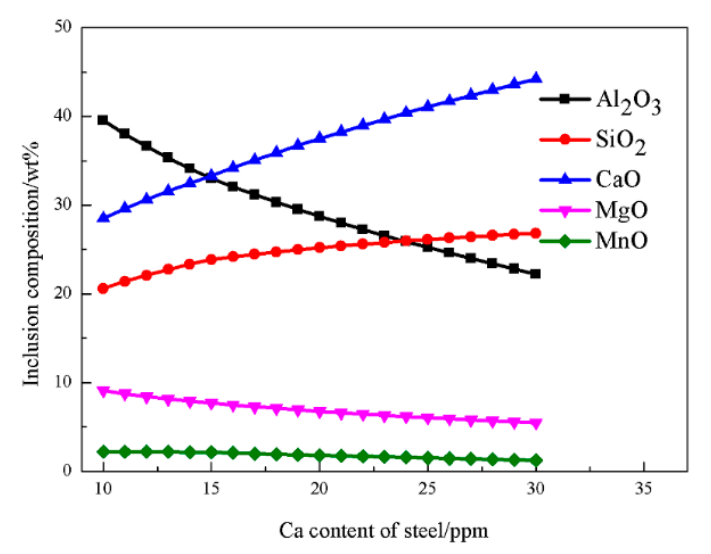

Figure 6. Inclusion composition as a function of the Ca content. 
The inclusion composition as a function of the $\mathrm{Al}$ content is presented in Figure 7 when the $\mathrm{O}$ content, Ca content, $\mathrm{Mg}$ content, and the temperatures are $0.007 \%, 0.002 \%, 0.0005 \%$, and $1600{ }^{\circ} \mathrm{C}$ respectively. It was observed that an increase in the $\mathrm{Al}$ content results in an increase in the $\mathrm{Al}_{2} \mathrm{O}_{3}$ content and a decrease in $\mathrm{CaO}$ and $\mathrm{SiO}_{2}$ contents; however, the $\mathrm{MgO}$ and $\mathrm{MnO}$ contents did not change much. With regard to the results described by Qian [18], it is worth noting that the $\mathrm{Al}$ content comes from the ferrosilicon. A large part of the aluminum reacts with oxygen to form $\mathrm{Al}_{2} \mathrm{O}_{3}$ inclusions, and the remaining aluminum is involved in the steel-slag reaction, thereby resulting in the fluctuation of the $\mathrm{Al}$ content. This is another reason for the fluctuations in the compositions of the endogenous inclusions that are smaller than $5 \mu \mathrm{m}$.

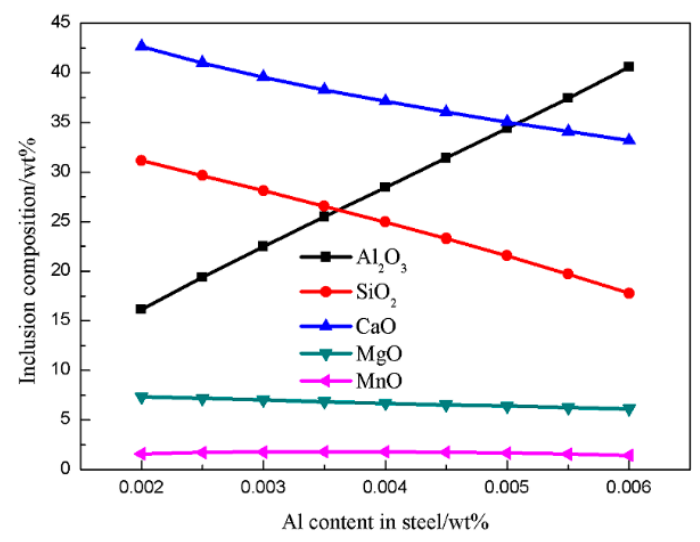

Figure 7. Inclusion composition as a function of the $\mathrm{Al}$ content.

The temperature was $1550{ }^{\circ} \mathrm{C}$ at the beginning of the VOD process, the highest temperature was $1650{ }^{\circ} \mathrm{C}$ at the oxygen blowing stage, and the final steel temperature was $1600{ }^{\circ} \mathrm{C}$; therefore, the temperature changed during the VOD refining process. The relationship between the inclusion composition and the temperature was calculated by using the FToxid and FTmisc databases of Factsage $^{\mathrm{TM}} 7.1$ when the $\mathrm{O}$ content, Ca content, $\mathrm{Mg}$ content, and the $\mathrm{Al}$ content were $0.007 \%, 0.002 \%$, $0.0005 \%$ and $0.004 \%$, respectively, and the result are shown in Figure 8. It can be seen that each inclusion composition changes with the changing temperature. The $\mathrm{CaO}$ content in the inclusion first increases and then decreases. The $\mathrm{Al}_{2} \mathrm{O}_{3}$ and $\mathrm{MgO}$ contents first decrease from $1650{ }^{\circ} \mathrm{C}$ to $1610{ }^{\circ} \mathrm{C}$, and then increase. The change trends of $\mathrm{MgO}$ and $\mathrm{SiO}_{2}$ in the inclusion are just the opposite. The $\mathrm{MnO}$ content increases gradually with the decrease in the temperature. The oxidation reaction with $\mathrm{Ca}, \mathrm{Al}$, $\mathrm{Mg}, \mathrm{Si}$, and $\mathrm{Mn}$ are exothermic, so that all of the reactions will occur as the temperature decreases. However, since $\mathrm{Ca}$ is a strong oxidizing element, and the concentration of $\mathrm{Si}$ in the molten steel is high, the deoxidation reaction of $\mathrm{Ca}$ and $\mathrm{Si}$ takes precedence. The $\mathrm{CaO}$ and $\mathrm{SiO}_{2}$ contents in the inclusion increase, while the $\mathrm{Al}_{2} \mathrm{O}_{3}$ and $\mathrm{MgO}$ contents in the inclusion decrease. With continuing deoxidation, the $\mathrm{CaO}$ and $\mathrm{SiO}_{2}$ concentrations decrease relatively, triggering an increase in $\mathrm{Al}_{2} \mathrm{O}_{3}$ and $\mathrm{MgO}$. The change in the temperature during the VOD refining process is one important reason for the fluctuations in the composition of the endogenous inclusions that are smaller than $5 \mu \mathrm{m}$. 


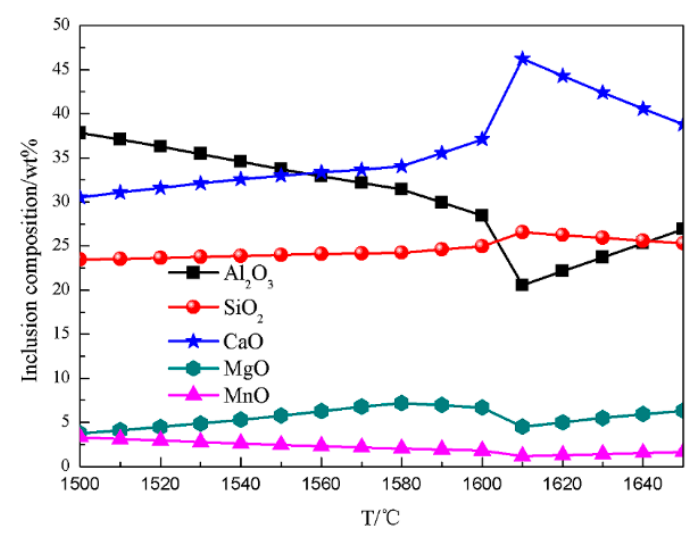

Figure 8. Inclusion composition as a function of the temperature.

The schematic illustration of the formation mechanism of the $\mathrm{CaO}-\mathrm{SiO}_{2}-\mathrm{Al}_{2} \mathrm{O}_{3}-\mathrm{MgO}-\mathrm{MnO}$ inclusions is shown in Figure 9. The oxidation of $\mathrm{Si}$ and $\mathrm{Al}$ and the collision result in the modification of the smaller-sized inclusions; the reactions are shown in Equations (1)-(3). The source of the total contents of $\mathrm{Ca}$ and $\mathrm{Mg}$ mainly comes from the addition of $\mathrm{FeSi}$ and the reduction of $\mathrm{CaO}$ and $\mathrm{MgO}$ in the slag or refractory. The appearance of $\mathrm{MnO}$ in the inclusions is related to the VOD process; the high oxygen and manganese contents in the liquid steel in part lead to these inclusions.

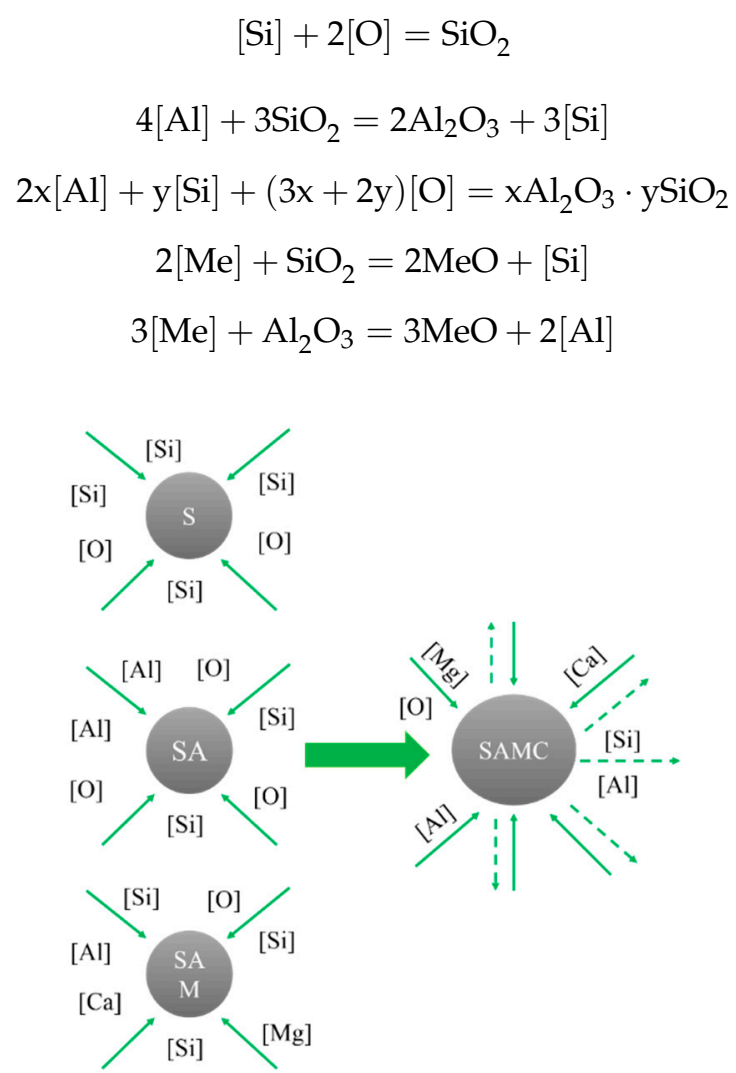

Figure 9. Schematic illustration of the formation mechanism of the $\mathrm{CaO}-\mathrm{SiO}_{2}-\mathrm{Al}_{2} \mathrm{O}_{3}-\mathrm{MgO}-$ $\mathrm{MnO}$ inclusions.

\section{Conclusions}

(1) The compositional characteristics indicated that two types of inclusions with different sizes existed in the $304 \mathrm{~L}$ stainless steel during the VOD refining process, namely, $\mathrm{CaO}-\mathrm{SiO}_{2}-\mathrm{Al}_{2} \mathrm{O}_{3}-\mathrm{MgO}$ external inclusions with sizes ranging from several to tens of microns, and $\mathrm{CaO}-\mathrm{SiO}_{2}-\mathrm{Al}_{2} \mathrm{O}_{3}-\mathrm{MgO}-\mathrm{MnO}$ 
endogenous inclusions with sizes smaller than $5 \mu \mathrm{m}$. The main inclusion type was $\mathrm{CaO}_{-} \mathrm{SiO}_{2}-$ $\mathrm{Al}_{2} \mathrm{O}_{3}-\mathrm{MgO}-\mathrm{MnO}$.

(2) The inclusion composition changed with an increasing size of the inclusions from $1 \mu \mathrm{m}$ to $30 \mu \mathrm{m}$. Most of the inclusions were smaller than $5 \mu \mathrm{m}$.

(3) The inclusions that were larger than $5 \mu \mathrm{m}$ were mostly $\mathrm{CaO}-\mathrm{SiO}_{2}-\mathrm{Al}_{2} \mathrm{O}_{3}-\mathrm{MgO}$; the similarity in composition to the slag indicated that these inclusions originated from slag entrapment. The $\mathrm{CaO}-\mathrm{SiO}_{2}-\mathrm{Al}_{2} \mathrm{O}_{3}-\mathrm{MgO}-\mathrm{MnO}$ inclusions that were smaller than $5 \mu \mathrm{m}$ mostly originated from an oxidation reaction with $\mathrm{Ca}, \mathrm{Al}, \mathrm{Mg}, \mathrm{Si}$, and $\mathrm{Mn}$. The changes in the inclusion composition resulting from changes in the $\mathrm{Ca}, \mathrm{Al}$, and $\mathrm{O}$ contents, and the temperatures during the VOD refining process were larger for the smaller inclusions.

Author Contributions: Conceptualization, G.C.; Methodology, X.C. and J.L.; Software, J.L. and Y.H.; Validation, X.C., J.L. and Y.H.; Formal Analysis, X.C.; Investigation, X.C.; Resources, X.C.; Data Curation, X.C.; Writing-Original Draft Preparation, X.C; Writing-Review \& Editing, Y.H.; Visualization, X.C.; Supervision, G.C.; Project Administration, J.P. and Q.R.

Funding: This research received no external funding.

Acknowledgments: The authors gratefully express their appreciation towards the National Nature Science Foundation of China (Grant No. 51374020), the State Key Laboratory of Advanced Metallurgy at University of Science and Technology Beijing (USTB), and Jiuquan Iron and Steel Group Corporation for supporting this work.

Conflicts of Interest: The authors declare no conflict of interest.

\section{References}

1. Chen, X.; Pan, J. Analysis on microstructure and inclusions of slab surface layer in 304L stainless steel. Contin. Casting 2018, 43, 44-48.

2. Momeni, A.; Abbasi, S.M. Repetitive Thermomechanical processing towards ultra fine grain structure in 301, 304 and 304L stainless steels. J. Mater. Sci. Technol. 2011, 27, 338-343. [CrossRef]

3. Amine, T.; Kriewall, C.S.; Newkirk, J.W. Long-term effects of temperature exposure on SLM 304L stainless steel. JOM 2018, 70, 384-389. [CrossRef]

4. Padhy, N.; Ningshen, S.; Panigrahi, B.K.; Mudali, U.K. Corrosion behaviour of nitrogen ion implanted AISI type 304L stainless steel in nitric acid medium. Corros. Sci. 2010, 52, 104-112. [CrossRef]

5. Mizuno, K.; Todoroki, H.; Noda, M.; Tohge, T. Effects of Al and Ca in ferrosilicon alloys for deoxidation on inclusion composition in type 304 stainless steel. Iron Steelmak. 2001, 28, 93-101.

6. Park, J.H.; Kang, Y.B. Effect of ferrosilicon addition on the composition of inclusions in 16Cr-14Ni-Si stainless steel melts. Metall. Mater. Trans. B 2006, 37, 791-797. [CrossRef]

7. Li, L.; Cheng, G.; Hu, B.; Wang, C.; Qian, G. Formation of Non-metallic Inclusions of Si-killed Stainless Steel during GOR Refining Process. High Temp. Mater. Proc. 2018, 37, 521-529. [CrossRef]

8. Kim, J.W.; Kim, S.K.; Kim, D.S.; Lee, Y.D.; Yang, P.K. Formation mechanism of Ca-Si-Al-Mg-Ti-O inclusions in type 304 stainless steel. ISIJ Int. 1996, 36, S140-S143. [CrossRef]

9. Ehara, Y.; Yokoyama, S.; Kawakami, M. Control of formation of spinel inclusion in type 304 stainless steel by slag composition. Tetsu-to-Hagané 2007, 93, 475-482. [CrossRef]

10. Yin, X.; Sun, Y.H.; Yang, Y.D.; Bai, X.F.; Deng, X.X.; Barati, M.; McLean, A. Inclusion evolution during refining and continuous casting of 316L stainless steel. Ironmak. Steelmak. 2016, 43, 533-540. [CrossRef]

11. Park, J.H.; Lee, S.B.; Kim, D.S. Inclusion control of ferritic stainless steel by aluminum deoxidation and calcium treatment. Metall. Mater. Trans. B 2005, 36, 67-73. [CrossRef]

12. Ren, Y.; Zhang, L.; Fang, W.; Shao, S.; Yang, J.; Mao, W. Effect of Slag Composition on Inclusions in Si-Deoxidized 18Cr-8Ni Stainless Steels. Metall. Mater. Trans. B 2016, 47, 1024-1034. [CrossRef]

13. Yan, P.; Huang, S.; Pandelaers, L.; Van Dyck, J.; Guo, M.; Blanpain, B. Effect of the CaO- $\mathrm{Al}_{2} \mathrm{O}_{3}$ based top slag on the cleanliness of stainless steel during secondary metallrugy. Metall. Mater. Trans. B 2013, 44, 1105-1119. [CrossRef]

14. Yan, P.; Huang, S.; Guo, M.; Blanpain, B. Desulphurisation and inclusion behaviour of stainless steel refining by using $\mathrm{CaO}-\mathrm{Al}_{2} \mathrm{O}_{3}$ based slag at low sulphur levels. ISIJ Int. 2014, 54, 72-81. [CrossRef] 
15. Sakata, K. Technology for production of austenite type clean stainless steel. ISIJ Int. 2006, 46, $1795-1799$. [CrossRef]

16. Park, J.H.; Lee, S.B.; Gaye, H.R. Thermodynamics of the formation of $\mathrm{MgO}-\mathrm{Al}_{2} \mathrm{O}_{3}-\mathrm{TiO}_{\mathrm{x}}$ inclusions in Ti-stabilized 11Cr ferritic stainless steel. Metall. Mater. Trans. B 2008, 39, 853-861. [CrossRef]

17. Kang, Y.B.; Lee, H.G. Inclusions chemistry for Mn/Si deoxidized steels: Thermodynamic predictions and experimental confirmations. ISIJ Int. 2004, 44, 1006-1015. [CrossRef]

18. Qian, G.; Qu, Z.; Cheng, G. Effect of Al in FeSi alloy on continuous casting and surface defect of stainless steel hot-rolled sheet. Iron Steel 2016, 51, 76-81.

19. Qian, G. The Technologies and Theory of Desulfurization and Inclusion Control for 304 Stainless Steel on GOR Process. Ph.D. Thesis, University of Science and Technology Beijing, Beijing, China, 2015.

20. Swinbourne, D.R.; Kho, T.S.; Langberg, D.; Blanpain, B.; Arnout, S. Understanding stainless steelmaking through computational thermodynamics Part 2-VOD converting. Miner. Process. Extr. Metall. 2010, 119, 107-115. [CrossRef]

21. Wei, J.H.; Li, Y. Study on Mathematical Modeling of Combined Top and Bottom Blowing VOD Refining Process of Stainless Steel. Steel Res. Int. 2015, 86, 189-211. [CrossRef]

(C) 2018 by the authors. Licensee MDPI, Basel, Switzerland. This article is an open access article distributed under the terms and conditions of the Creative Commons Attribution (CC BY) license (http:/ / creativecommons.org/licenses/by/4.0/). 